\title{
Pressure pain threshold and pain perception in temporomandibular disorder patients: is there any correlation?
}

\author{
Limiar de dor à pressão e percepção da dor em pacientes com disfunção temporomandibular: \\ existe alguma correlação?
}

Juliana Stuginski-Barbosa¹, Rafael Santos Silva², Carolina Ortigosa Cunha', Leonardo Rigoldi Bonjardim¹, Ana Cláudia de Castro Ferreira Conti ${ }^{3}$, Paulo César Rodrigues Conti ${ }^{1}$

${ }^{*}$ Received from Bauru School of Dentistry, University of Sao Paulo, Bauru, SP, Brazil.

\section{ABSTRACT}

BACKGROUND AND OBJECTIVES: Physical evaluation of temporomandibular disorder patients commonly includes evaluation of pain response to muscular and articular palpation and there is a considerable uncertainty of how self-reported pain intensity relates to Pressure Pain Threshold obtained in an algometry exam. The present study aimed at determining whether pain intensity is associated to Pressure Pain Threshold in temporomandibular disorder patients.

METHODS: Eighty arthralgia patients and one hundred and thirty masticatory myofascial pain patients participated in this study. Pain intensity was recorded with visual analog scale. Pressure Pain Threshold was measured using a pressure algometer. Pressure was applied bilaterally on the temporomandibular joint in arthralgia patients and masseter and anterior temporalis muscles. Pearson correlation coefficient ( $\mathrm{r}$ ) was calculated to determine the strength of the relationship between pain intensity and the lowest Pressure Pain Threshold value in each site.

RESULTS: The correlation between all pain intensity and Pressure Pain Threshold values was statistically weak. Correlations between pain intensity and joint Pressure Pain Threshold ( $\mathrm{r}=-$ 0.236; $\mathrm{p}=0.035)$ in the arthralgia group and pain intensity and masseter's Pressure Pain Threshold $(\mathrm{r}=-0.312 ; \mathrm{p}<0.001)$ and between pain intensity and anterior temporalis Pressure Pain Threshold ( $\mathrm{r}=-0.240 ; \mathrm{p}=0.006)$ were statistically significant.

CONCLUSION: The weak correlation between pain intensity

1. University of Sao Paulo, Bauru School of Dentistry, Bauru, SP, Brazil.

2. State University of Parana, Brazil, Maringá, PR. Brazil.

3. University of Northern Parana, Brazil, Londrina, PR, Brazil.

Submitted in November 09, 2014.

Accepted for publication in February 03, 2015.

Conflict of interests: none - Sponsoring sources: none.

Correspondence to:

Juliana Stuginski-Barbosa

Alameda Otávio Pinheiro Brizola, 9-75

17012-901 Bauru, SP, Brasil.

E-mail: juliana.dentista@gmail.com

(C) Sociedade Brasileira para o Estudo da Dor and Pressure Pain Threshold suggests that other factors are clearly important in explaining the pain experience of temporomandibular disorder patients, including the contribution of central nervous system nociceptive processes and psychological variables to the maintenance of chronic pain.

Keywords: Pain, Pain threshold, Temporomandibular joint disorders, Temporomandibular joint dysfunction syndrome.

\section{RESUMO}

JUSTIFICATIVA E OBJETIVOS: A avaliação clínica de pacientes com disfunção temporomandibular inclui a avaliação da resposta dolorosa à palpação muscular e articular e existe uma incerteza sobre como a intensidade da dor relatada pelo paciente se relaciona com o limiar de dor à pressáo obtido com exame de algometria. $\mathrm{O}$ presente estudo objetivou determinar se há uma associação entre essas duas variáveis.

MÉTODOS: Oitenta pacientes com artralgia e 130 com dor miofascial mastigatória participaram deste estudo. A intensidade de dor foi aferida com a escala visual analógica. O limiar de dor à pressão foi aferido utilizando o algômetro. A pressão foi aplicada bilateralmente na articulaçáo temporomandibular nos pacientes com artralgia e nos músculos masseter e temporal anterior. $\mathrm{O}$ teste utilizado na análise estatística foi o coeficiente de correlação de Pearson (r) para determinar a força da correlaçáo entre intensidade de dor e o menor valor de limiar de dor à pressão.

RESULTADOS: As correlaçóes entre os valores de intensidade de dor e limiar de dor à pressão foram estatisticamente fracas. As correlaçóes entre intensidade de dor e limiar de dor à pressão na articulação temporomandibular $(\mathrm{r}=-0,236 ; \mathrm{p}=0,03)$, no masseter $(\mathrm{r}=-0,312 ; \mathrm{p}<0,001)$ e no temporal anterior $(\mathrm{r}=-0,240 ; \mathrm{p}=0,006)$ foram estatisticamente significantes.

CONCLUSÁO: A baixa correlação entre intensidade de dor e limiar de dor à pressão sugere que outros fatores possam ser claramente importantes para explicar a experiência dolorosa de pacientes com disfunçáo temporomandibular, incluindo a contribuição do processo nociceptivo no sistema nervoso central e as variáveis psicossociais para a manutenção da dor crônica.

Descritores: Dor, Limiar da dor, Síndrome da disfunção da articulação temporomandibular, Transtornos da articulação temporomandibular. 


\section{INTRODUCTION}

Quantitative sensory testing (QST) procedures have been used in clinical and research settings to assess pain threshold ${ }^{1}$. The common concepts in QST methods are that the assessment of normal and non-normal responses to various stimuli provides information about the functioning of the peripheral and central nervous system. These responses can be quantified by the amount of physical stimuli required to evoke specific levels of sensory perception ${ }^{2}$. QST battery assembles a list of short form tests representing measurements of all relevant factors of the somatosensory system ${ }^{1}$.

Pressure Pain Threshold (PPT) is one of these tests and it is defined as the minimum force applied which induces pain. This measure has proven to be commonly useful in evaluating muscles and articular tenderness symptoms, which are associated to painful musculoskeletal conditions, as well as for diagnosis of such conditions and for management strategies efficacy analysis ${ }^{3-5}$. The use of an algometer (pressure device that induces mechanical stimuli) is to standardize the amount of pressure applied, similar to that when performing muscle palpation. It can improve reliability for the assessment of deep pain sensitivity ${ }^{6}$. Pain and tenderness in masticatory muscles are common findings in temporomandibular disorder (TMD) population ${ }^{7}$. Since the diagnosis of articular and muscular pain involves a report of pain during the palpation exam, PPT is commonly used to quantify muscle tenderness 8 .

In the literature it was described that reduction of PPT values occurring in TMD patients, ${ }^{5,9-12}$ can be explained by both peripheral and central mechanisms. In peripheral, tissue injury increases the excitability of nociceptors membrane that will reduce the amount of action potential required to initiate a depolarization (reducing nociceptor threshold). Peripheral hyperexcitability can increase ascending signaling to the brain while reducing descending inhibitory signals, precipitating spontaneous and widespread pain, leading to central sensitization ${ }^{10}$. Superficial somatic pain is the result of a lowered pain threshold, and because the site of pain and the location of its true source are the same, the discomfort that results from provocation at the site of pain is related faithfully to the stimulus ${ }^{13}$.

Patients' description of pain and their self-report of pain intensity can be the most accurate and reliable evidence of pain and its intensity. So it is tempting to speculate that PPT is strongly associated to the intensity of pain experienced by TMD patients ${ }^{7}$. The hypothesis is that scores of both measures (PPT and self-reported pain intensity) might reflect the severity of the condition and be strongly associated, especially when PPT is performed at the same location of the reported pain. Lower PPT close to the site of injury or related pain seems to reflect peripheral nociceptors sensitization and has been reported in patients with $\mathrm{TMD}^{14}$ when compared to healthy controls ${ }^{9,11,12,15}$.

Few studies have investigated the relationship between pain report and PPT in TMD patients and none has observed this relationship in arthralgia patients. The findings have been inconsistent. List, Helkimo \& Karlsson ${ }^{16}$ analyzed the correlation between PPT and pain intensity rated by a visual analogue scale
(VAS) in TMD patients immediately after treatment. The PPT test was performed at the belly of masseter muscle and a weak but significant correlation was found between PPT and pain intensity. In contrast, Isselée et al. reported that VAS pain rating did not correlate with PPT in patients with masticatory myofascial pain, and the statistical analysis showed that VAS ratings could not be used as predictors for PPT measurements ${ }^{8}$.

A physical assessment of TMD patients commonly includes evaluation of pain in response to muscle and temporomandibular joint (TMJ) palpation and there is a considerable uncertainty of how the intensity of reported pain relates to PPT.

The aim of this study was to assess, compare and determine whether self-reported pain intensity (PI) is correlated to an experimental pain stimulus induced by an algometer (PPT values) close to the site of presumed tissue damage in TMD patients.

\section{METHODS}

Participants were selected among patients presenting for treatment at the Orofacial Pain Clinic at Bauru School of Dentistry - University of Sao Paulo, with diagnosis of articular or muscular TMD according to the Research Diagnostic Criteria for Temporomandibular Disorders (RDC/TMD) Axis I. A comprehensive history was taken and all patients were clinically examined regarding pain and dysfunction signals and symptoms of the stomatognathic system before being included in the study.

Inclusion criteria were as follows: age between 18 and 65 years, fluent in spoken and written Portuguese and pain in masticatory muscles or TMJ for at least 3 months in accordance with the RDC/TMD. Exclusion criteria included patients with systemic disease like fibromyalgia or rheumatic conditions, odontogenic or neuropathic pain and history of TMJ surgery. Patients on ongoing use of medication, such as analgesics, benzodiazepines, antipsychotics or antidepressants were also excluded.

Participants were divided into two groups: arthralgia patients and miofascial pain patients according to the RDC/TMD diagnosis.

Eighty arthralgia patients $(\mathrm{n}=80)$ and one hundred and thirty $(\mathrm{n}=130)$ myofascial patients participated in this study. Seventyeight $(\mathrm{n}=78)$ arthralgia patients $(97.5 \%)$ and 120 myofascial patients $(92.3 \%)$ were females. One calibrated and experienced operator evaluated each group.

At baseline participants independently rated their present pain intensity (PI) on a VAS. The VAS was a $100-\mathrm{mm}$ line in which the patient recorded pain intensity by marking a point on the line between the two extremes where the left extreme of the scale is marked "no pain" and the right one is marked "the worst imaginable pain". VAS is a simple, efficient, reliable and valid method to measure pain intensity and is extensively used in clinical settings and researches ${ }^{18,19}$.

PPT was measured using a pressure digital algometer with a 1 $\mathrm{cm}^{2}$ flat-circular shape tip at one end (Kratos Equipamentos Industriais). The probe tip was covered with a 1-mm-thick rubber pad to minimize irritation of the skin. The probe was held perpendicularly at each assessment site to apply the pressure over the TMJ or muscles. Pressure application rate was set approxi- 
mately at $0.5 \mathrm{kgf} / \mathrm{cm}^{2} / \mathrm{sec}^{9}$. The participant was asked to indicate when the sensation changed from pressure only to pressure and pain using a hand-held switch that recorded the PPT value in the digital algometer when triggered, and at that moment the pressure was stopped and the value displayed. The device used in the present study has a button, controlled by the patient, who is asked to press it at the very beginning of pain sensation. Before PPT measurements, each patient underwent a short training for familiarization with the algometer, its hand-held device and its application method.

In arthralgia patients, PPT (PPT/TMJ) was measured once at the lateral pole of the temporomandibular joint (TMJ) on both sides. Before the assessment, TMJ lateral poles were located asking the patient to open and close the mouth three times with the operator's finger placed in front of the tragus. In myofascial pain patients, PPT was measured once at masseter muscles (PPTm) and anterior temporalis (PPTat) muscles on both sides in a relaxed posture. During the examination, the operator's hand passively supported the individual's head. Reliable data can be obtained from an algometer if all the factors are standardized, like size of tip, rate of pressure and degree of muscle contraction ${ }^{9}$.

\section{Statistical analysis}

For statistical analysis, PPT values of the side that was the most painful according to the patient's report were used. When bilateral, the most painful side was chosen by the operator.

Mean and standard deviation (SD) of each variable were described. Two $t$ tests were used to compare the two groups by variables scores.

Pearson correlation coefficient ( $r$ ) was calculated to determine the strength of the relationship between PI and the lowest PPT in each assessed site. Statistical significance was set at $\mathrm{p}<0.05$. Confidence intervals around Pearson $\mathrm{r}$ coefficient were calculated using a transformation to the Fisher $\mathrm{z}$ statistic.

Ethics clearance for the study was granted by Bauru School of Dentistry (protocols: \#026/2002 and \#042/2009) and consent form was obtained from all subjects. The present study was conducted in accordance to the Helsinki Declaration of 1975, revised in 1983 .

\section{RESULTS}

Mean age for arthralgia patients was $40.84 \pm 12.19$ years old and $37.48 \pm 11.74$, for myofascial pain patients. There was no significant difference between groups regarding mean age $[2 \mathrm{t}$ Test; p $>0.05$; 95\%CI $(-0.01 ; 6.73)]$. Self-reported (VAS) pain intensity was $6.853 \pm 0.163 \mathrm{~cm}$ for arthralgia patients and $4.834 \pm 2.560$ $\mathrm{cm}$ for myofascial pain patients. Pain intensity was significantly higher in arthralgia group patients $[2 \mathrm{t}$ test; $\mathrm{p}<0.001 ; 95 \% \mathrm{CI}$ $(1.573 ; 2.465)]$. Pressure pain threshold mean in the TMJ was $1.07 \pm 0.44 \mathrm{kgf} / \mathrm{cm}^{2}$; in masseter, $1.329 \pm 0.479 \mathrm{kgf} / \mathrm{cm}^{2}$ and in the anterior temporalis, $1.89 \pm 0.593 \mathrm{kgf} / \mathrm{cm}^{2}$.

No correlation between age and PPT was found for any group. The correlation between PI and PPT values was statistically weak, but significant in arthralgia (PPTtmj) patients $[r=-0.236$; $\mathrm{p}=0.035 ; 95 \%$ CI $(-0.433 ;-0.018)]$ (Figure 1$)$ and in myofascial pain patients between PI and PPTm $[-0.312$; $\mathrm{p}<0.001 ; 95 \% \mathrm{CI}(-$ $0.465 ;-0.141)]$ (Figure 2) and between PI and PPTat $[r=-0.240$; $\mathrm{p}=0.006 ; 95 \%$ CI $(-0.401 ;-0.064)$ ] (Figure 3).

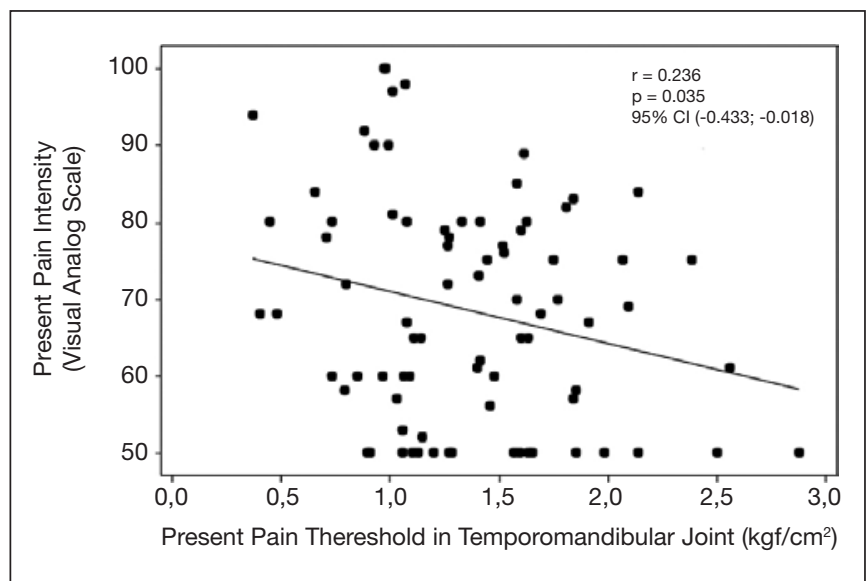

Figure 1. Correlation between pressure pain threshold in temporomandibular joint $\left(\mathrm{kgf} / \mathrm{cm}^{2}\right)$ and present pain intensity (visual analogue scale) in arthralgia patients $(n=80)$

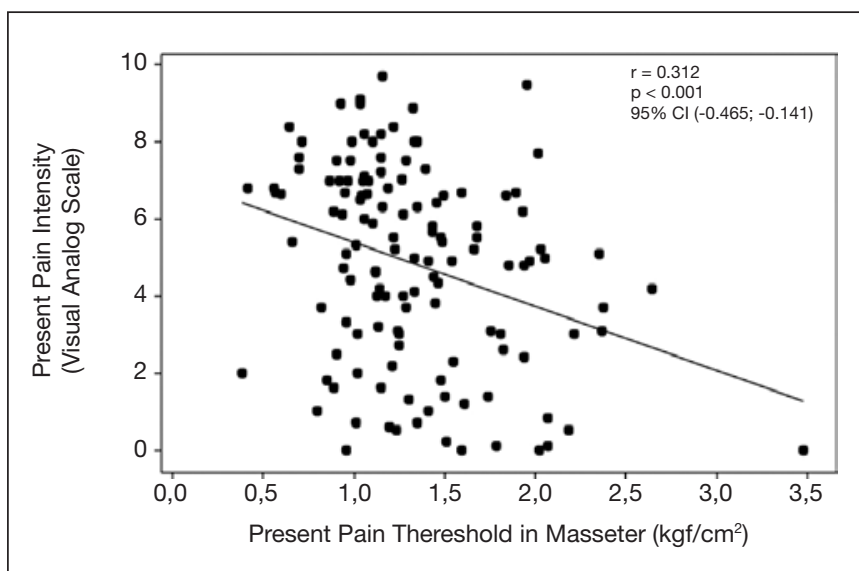

Figure 2. Correlation between pressure pain threshold in masseter muscle $\left(\mathrm{kgf} / \mathrm{cm}^{2}\right)$ and present pain intensity (visual analogue scale) in myofascial pain patients $(n=130)$

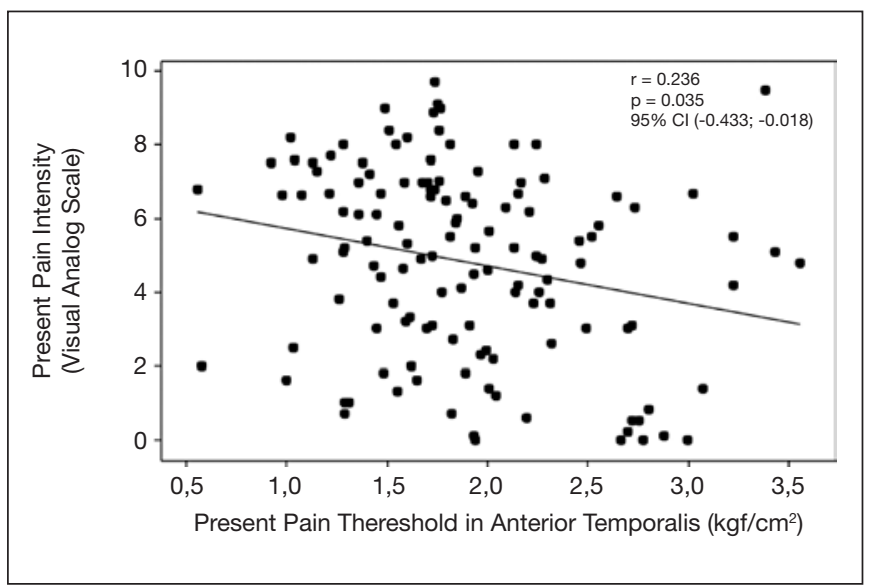

Figure 3. Correlation between pressure pain threshold in anterior temporalis muscle $\left(\mathrm{kgf} / \mathrm{cm}^{2}\right)$ and present pain intensity (visual analogue scale) in myofascial pain patients $(n=130)$ 


\section{DISCUSSION}

The relationship between pain and increased sensitivity to pressure in TMD patients is not as simple as it was hypothesized. In this study, a weak association was found between PI and PPT in TMJ and masticatory muscles, as observed at the initial assessment. It was a surprising result as it was expected that those subjects with severe pain might be expected to have greater sensitivity and lower PPT values. These findings suggest that mechanical sensitivity may not explain the pain reported by TMD patients. Pain has been accepted as a sensation influenced by several aspects, so it is hard to determine how much of self-reported pain is a result of local stimulation of the injured site or it is due to an emotional component ${ }^{20}$. PPT and VAS are subjective clinical measurement tools and can only approximate of a true measurement of pain ${ }^{21}$. However, as both are assessing pain, it might be reasonable to expect that correlations would reach at least a value of $0.5^{22}$. Our findings for masseter muscle PPT/ VAS correlation were similar to List, Helkimo \& $\mathrm{Karlsson}^{16}$. While results for PPT were in agreement with results of selfreported pain intensity recording in both studies, the strength of this correlation was weak. As reported by Isselée et al. ${ }^{8}$, pain intensity rated by VAS did not correlate with PPT values. Although in another study PPT test performed in an extra oral site (hand) in masticatory myofascial pain patients showed that most patients with lowest values for PPT in the hand had VAS mean scores greater than 5 (out of 10), even though this finding was not statically significant ${ }^{23}$.

Our findings are also similar to those observed in patients with whiplash injuries ${ }^{21}$, fibromyalgia ${ }^{25}$ and other chronic pain conditions ${ }^{3}$.

PPT value reflects the pressure value that the individual first perceived to be painful ${ }^{1}$. Decreased PPT could reflect an increased excitability at any point of the nociceptive pathway ${ }^{25}$. There is a pronounced difference between PPT in patients and asymptomatic controls, which has been shown in a large case-control study, where a variety of mechanical and thermal stimuli were tested ${ }^{7}$. The algometer has been tested and used in research and clinical settings, with good reliability and validity in TMJ and masticatory muscles? ${ }^{9}$ In the present study the patient was carefully informed about the procedures and the measurements were performed in a quiet room as recommended by Laursen et al. ${ }^{3}$. However, it is possible that the placement of the algometer did not directly stress the injured tissues in TMJ and masticatory muscles, despite being within the area of self-reported pain ${ }^{21}$, which could explain actual results. Masseter muscle had the lowest PPT value. In fact, it was described that this part of the masseter muscle seems to be the most sensitive predictor of tenderness of all masticatory muscles tested ${ }^{9,16}$.

The use of pain scales in clinical and pain studies settings is widely disseminated in the pain field since these rating scales are simple, economic and easy for patients to understand. However, these scales assume pain to be one-dimensional experience that can vary only in intensity ${ }^{20}$. When asking patients to indicate the level of pain intensity on a continuous VAS, even after careful instruction, it could be difficult for the patient to separate pain perception from others emotional factors ${ }^{3}$. VAS scores for pain intensity in the present study were very similar to those reported in earlier studies on masticatory myofascial pain patients $s^{8,23}$, TMD and others chronic pain conditions ${ }^{3,21}$.

Our study has relevant limitations. First, as described in the literature, self-reported TMD pain could be shaped by psychologi$\mathrm{cal}$, behavioral and even genetic factors ${ }^{23}$. Stress and anxiety can influence muscle PPT and pain report in masticatory myofascial pain patients. TMD patients show higher levels of catastrophizing complaints, depression and/or anxiety symptoms as well as poor quality of sleep. Moreover, patients also tend to overestimate their pre-treatment pain levels ${ }^{20}$. However, we were unable to explore the influence of these factors in the present investigation, which could explain some results.

Significant PPT values could be found higher in men than in women in TMD patients ${ }^{16}$. Among healthy individuals, women showed greater pain sensitivity than men $^{7}$. In the present study, there was insufficient power in statistical analysis for the comparison between genders, since only $5.7 \%$ of the sample was male. In fact, studies described that TMD is more prevalent in women. Predisposition for this involves many factors like female hormonal events, comorbidities, psychological factors and upregulated nociceptive mechanisms ${ }^{7}$.

Even knowing that reliable data can be obtained from an algometer if all parameters are standardized ${ }^{9}$, in this study there was no reliability and reproducibility analysis of current data as well as the number of evaluated sites was restricted.

The influence of central nervous system changes on pain selfreport takes a longer time to have some real effect. PPT and PI could be affected by the presence of chronic pain. As central sensitization is a process that needs time to occur and characterizes chronic pain ${ }^{21}$, pain duration could be a confounder factor, and it was not evaluated in the present study.

\section{CONCLUSION}

A statistically significant correlation between PI and PPT was observed in both arthralgia and myofascial pain TMD patients. However, the weakness of these correlations suggests that other factors are clearly important in explaining pain experience of TMD patients, including the contribution of nociceptive processes in the central nervous system and psychological variables. Besides, it is extremely important to explore in future studies the standardization of algometer devices and algometry exam.

\section{REFERENCES}

1. Svensson P, Baad-Hansen L, Pigg M, List T, Eliav E, Ettlin D, et al. Guidelines and recommendations for assessment of somatosensory function in oro-facial pain conditions--a taskforce report. J Oral Rehabil. 2011;38(5):366-94.

2. Porporatti AL, Costa YM, Stuginski-Barbosa J, Bonjardim LR, Conti PC, Svensson P. Quantitative methods for somatosensory evaluation in atypical odontalgia. Braz Oral Res. 2015;29(1):1-7.

3. Laursen BS, Bajaj P, Olesen AS, Delmar C, Arendt-Nielsen L. Health related quality of life and quantitative pain measurement in females with chronic non-malignant pain. Eur J Pain. 2005;9(3):267-75.

4. Fredriksson L, Alstergren P, Kopp S. Absolute and relative facial pressure-pain thresholds in healthy individuals. J Orofac Pain. 2000;14(2):98-104.

5. McMillan AS, Blasberg B. Pain-pressure threshold in painful jaw muscles following trigger point injection. J Orofac Pain. 1994;8(4):384-90. 
6. Isselée H, De Laat A, De Mot B, Lysens R. Pressure-pain threshold variation in temporomandibular disorder myalgia over the course of the menstrual cycle. J Orofac Pain. 2002;16(2):105-17.

7. Santos Silva RS, Conti PC, Lauris JR, da Silva RO, Pegoraro LF. Pressure pain threshold in the detection of masticatory myofascial pain: an algometer-based study. J Orofac Pain. 2005;19(4):318-24.

8. Michelotti A, Farella M, Stellato A, Martina R, De Laat A. Tactile and pain thresholds in patients with myofascial pain of the jaw muscles: a case-control study. J Orofac Pain. 2008;22(2):139-45.

9. Ohrbach R, Gale EN. Pressure pain thresholds, clinical assessment, and differential diagnosis: reliability and validity in patients with myogenic pain. Pain. 1989;39(2):157-69.

10. Svensson P, Arendt-Nielsen L, Nielsen H, Larsen JK. Effect of chronic and experimental jaw muscle pain on pain-pressure thresholds and stimulus-response curves. J Orofac Pain. 1995;9(4):347-56.

11. Okeson JP. The classification of orofacial pains. Oral Maxillofac Surg Clin North Am. 2008;20(2):133-44

12. Vazquez-Delgado E, Schmidt JE, Carlson CR, DeLeeuw R, Okeson JP. Psychological and sleep quality differences between chronic daily headache and temporomandibular disorders patients. Cephalalgia. 2004;24(6):446-54.

13. Farella M, Michelotti A, Steenks MH, Romeo R, Cimino R, Bosman F. The diagnostic value of pressure algometry in myofascial pain of the jaw muscles. J Oral Rehabil. 2000;27(1):9-14

14. List T, Helkimo M, Karlsson R. Pressure pain thresholds in patients with cranioman- dibular disorders before and after treatment with acupuncture and occlusal splint therapy: a controlled clinical study. J Orofac Pain. 1993;7(3):275-82.

15. Nielsen CS, Price DD, Vassend O, Stubhaug A, Harris JR. Characterizing individual differences in heat-pain sensitivity. Pain. 2005;119(1-3):65-74.

16. Price DD, McGrath PA, Rafii A, Buckingham B. The validation of visual analogue scales as ratio scale measures for chronic and experimental pain. Pain. 1983;17(1):45-56.

17. Price DD, Bush FM, Long S, Harkins SW. A comparison of pain measurement characteristics of mechanical visual analogue and simple numerical rating scales. Pain. 1994;56(2):217-26.

18. Conti PC, de Azevedo LR, de Souza NV, Ferreira FV. Pain measurement in TMD patients: evaluation of precision and sensitivity of different scales. J Oral Rehabil. 2001;28(6):534-9.

19. Kamper SJ, Maher CG, Hush JM, Pedler A, Sterling M. Relationship between pressure pain thresholds and pain ratings in patients with whiplash-associated disorders. Clin J Pain. 2011;27(6):495-501.

20. Guyatt GH, Norman GR, Juniper EF, Griffith LE. A critical look at transition ratings. J Clin Epidemiol. 2002;55(9):900-8.

21. Etoz OA, Ataoglu H. Evaluation of pain perception in patients with temporomandibular disorders. J Oral Maxillofac Surg. 2007;65(12):2475-8.

22. Carli G, Suman AL, Biasi G, Marcolongo R. Reactivity to superficial and deep stimuli in patients with chronic musculoskeletal pain. Pain. 2002;100(3):259-69.

23. Nijs J, Van Houdenhove B, Oostendorp RA. Recognition of central sensitization in patients with musculoskeletal pain: Application of pain neurophysiology in manual therapy practice. Man Ther. 2010;15(2):135-41 